Jurnal Manajemen dan Kewirausahaan, Volume 9, Nomor 3, September 2018

ISSN 2086-5031

E-ISSN 2615-3300

DOI 10.31317

\title{
Pengaruh Perceived Value Dan Fasilitas Terhadap Repurchase Intention Wisatawan Di Objek Wisata Gunung Padang
}

Oleh

Liza Zulbahri, Yuni Candra, Dian Utami

Program Studi Manajemen, Fakultas Ekonomi, Universitas Tamansiswa Padang lizazulbahri@yahoo.com,yuni.candra80@gmail.com

\begin{abstract}
Abstrak
Penelitian ini bertujuan untuk mengetahui seberapa besar pengaruh perceived value dan fasilitas terhadap repurchase intention wisatawan di objek wisata Gunung Padang. Metode penelitian yang digunakan adalah kuantitatif deskriptif dengan teknik purposive sampling. Sampel yang digunakan adalah 100 responden, instrumen yang digunakan dalam penelitian ini adalah kuesioner/angket. Dari uji t yang dilakukan didapatkan satu variabel berpengaruh signifikan terhadap repurchase intention wisatawan di objek wisata Gunung Padang yaitu fasilitas $\left(\mathrm{X}_{2}\right)$, dan terdapat satu variabel yang tidak berpengaruh signifikan terhadap repurchase intention wisatawan di objek wisata Gunung Padang yaitu variabel perceived value $\left(\mathrm{X}_{1}\right)$. Dari hasil uji $\mathrm{F}$ terbukti bahwa variabel perceived value dan fasilitas secara bersama-sama berpengaruh signifikan terhadap repurchase intention wisatawan di objek wisata Gunung Padang . Hasil koefisien determinasi didapatkan $21,5 \%$ sedangkan sisanya $78,5 \%$ dipengaruhi oleh variabel lain yang tidak dibahas dalam penelitian ini.
\end{abstract}

\section{Kata Kunci : Perceived Value, Fasilitas, Repurchase Intention}

\section{PENDAHULUAN}

\section{Latar Belakang}

Kota Padang terdapat objek wisata yang menarik, seperti objek wisata Gunung Padang, Masyarakat Padang menyebutnya sebagai Gunung Padang, karena memang puncak bukit ini merupakan wilayah yang paling tinggi yang terdapat di sekitar pusat Kota Padang. Taman Gunung Padang atau Taman Siti Nurbaya adalah sebuah tempat atau objek wisata yang berupa taman yang sangat indah yang berada di ketinggian yang terletak di sebelah barat Kota Padang. Untuk mencapai lokasi objek wisata ini kita cukup menuju ke arah Jembatan Siti
Nurbaya yang melintasi sungai Batang Arau di dekat Pelabuhan Muaro. Selanjutnya perjalanan dilanjutkan dengan menuju ke kawasan atau pintu gerbang Objek Wisata Gunuang Padang yang berjarak sekitar 500 meter dari Jembatan Siti Nurbaya.

Repurchase Intention pada objek wisata gunung padang adalah, karena lokasinya terletak di dekat pusat kota dan pantai Padang, serta akses menuju kesana tidak terlalu sulit, karena wisatawan bisa berkunjung ke sana dengan menggunakan kendaraan pribadi serta alat transportasi cukup memadai. tiket untuk memasuki 
Jurnal Manajemen dan Kewirausahaan, Volume 9, Nomor 3, September 2018

ISSN 2086-5031

E-ISSN 2615-3300

DOI 10.31317

wisata Gunung Padang relative murah, yaitu

Makam Siti Nurbaya, satu legenda besar Rp 5.000 per orang.

Jika wisatawan membutuhkan pemandu (Guide), penjaga loket akan bersedia untuk mencarikan seorang pemandu untuk mengantarkan wisatawan berkeliling dan memberikan informasi tentang sejarah seputar Gunung Padang. suasana pada objek wisata gunung padang memiliki keindahan alam yang hijau, serta banyak dipenuhi dengan pepohonan rindang, dan udara terasa sangat sejuk meski cahaya matahari sedang terik.

Perceived Value yang ditemukan pada objek wisata Gunung Padang adalah, bisa menikmati keindahan kota padang dan hamparan laut biru dari ketinggian. Segala penat yang dirasakan wisatawan ketika melakukan pendakian ke puncak Gunung Padang itu langsung hilang saat berbaring menatap hamparan langit, atau menyaksikan birunya laut pada pesisir pantai Sumatera Barat itu. selain itu juga bisa mengunjungi sejenak di daerah itu.

Fasilitas pada objek wisata Gunung Padang yaitu adanya bangunan tua bekas peninggalan pada masa pendudukan Jepang. Serta meriam yang digunakan oleh Jepang untuk mengawasi kapal yang keluar masuk Pelabuhan Muaro. Sebelum mencapai ke puncak Gunung Padang, wisatawan akan menemukan sebuah celah batu yang berbentuk gua dengan tangga menurun. Menurut keterangan salah seorang pemandu, tempat ini adalah lokasi makam dari Siti Nurbaya, tokoh utama dalam sebuah kisah legendaris Minangkabau. Serta dipertengahan jalan sebelum menuju ke puncak Gunung Padang, juga terdapat sebuah musholla dan beberapa tempat duduk yang telah disediakan untuk wisatawan yang ingin beristirahat ketika melakukan perjalanan ke puncak Gunung Padang.

Tabel 1: Data Pengunjung Di Objek Wisata Gunung Padang Sumatera Barat Tahun 2011-2016

\begin{tabular}{|c|c|c|}
\hline Tahun & Jumlah pengunjung & Persentase (\%) \\
\hline 2011 & 2,014 & - \\
\hline 2012 & 8,895 & $400 \%$ \\
\hline 2013 & 12,800 & $150 \%$ \\
\hline 2014 & 17,400 & $141 \%$ \\
\hline 2015 & 25,100 & $147 \%$ \\
\hline 2016 & 25,400 & $100 \%$ \\
\hline
\end{tabular}

Sumber : Dinas Pariwisata Sumatera Barat 2017

Program Studi Manajemen Fakultas Ekonomi Universitas Tamansiswa Padang 
Jurnal Manajemen dan Kewirausahaan, Volume 9, Nomor 3, September 2018

ISSN 2086-5031

E-ISSN 2615-3300

DOI 10.31317

Setelah sampainya di atas puncak wisata Gunung Padang, wisatawan akan dapat menikmati peristirahatan pada beberapa panorama alam dan tempat duduk, sekaligus dapat menikmati pemandangan alam kota padang dari ketinggian. Ditambah dengan sedang dibangunnya tulisan Padang pada puncak objek wisata Gunung Padang. Namun untuk toiletnya hanya terletak di area bawah sebelum menuju ke puncak gunung padang.

\section{Rumusan Masalah}

Berdasarkan latar belakang diatas, maka dapat dirumuskan masalah sebagai berikut :

1. Apakah Perceived Value berpengaruh signifikan terhadap repurchase intention wisatawan di objek Wisata Gunung Padang?

2. Apakah fasilitas berpengaruh signifikan terhadap Repurchase Intention wisatawan di objek Wisata Gunung Padang?

3. Apakah Perceived Value dan fasilitas berpengaruh signifikan terhadap repurchase intention wisatawan di objek Wisata Gunung Padang?

\section{Tujuan Penelitian}

Adapun tujuan yang ingin dicapai dalam penelitian ini adalah

1. Untuk mengetahui dan menganalisis pengaruh perceived value terhadap repurchase intention wisatawan di objek wisata Gunung Padang.?

2. Untuk mengetahui dn menganalisis pengaruh fasilitas terhadap repurchase intention wisatawan di objek wisata Gunung Padang.

3. Untuk mengetahui dan menganilisis perceived value dan fasislitas secara bersama-sama terhadap repurchase intention wisatawan di objek wisata Gunung Padang.

\section{LANDASAN TEORI}

\section{Pemasaran Jasa}

Menurut Sutiyaningrum et al (2015:281), pemasaran jasa terbagi atas dua produk yaitu barang dan jasa. Barang adalah produk yang berwujud, seperti pakaian, makanan, dan mainan anakanak.

\section{Pariwisata}

Pariwisata merupakan kegiatan melakukan perjalanan dengan tujuan mendatangkan kesenangan, mencari kepuasan, mencari sesuatu dan memperbaiki kesehatan, menikmati olah raga atau istirahat, menunaikan tugas, berziarah dan lain-lain (Anindita, 2015).

\section{Perceived Value}

Menurut Kristanto dalam Siry (2015:3), perceived value adalah persepsi pelanggan dalam membandingkan antara manfaat yang dirasakan dengan biaya yang dikeluarkan. Menurut Kristanto dalam Siry (2015:3), adapun indikator pengukuran variabel perceived value mengacu pada teori sebagai berikut:

a. Biaya 
Jurnal Manajemen dan Kewirausahaan, Volume 9, Nomor 3, September 2018

ISSN 2086-5031

E-ISSN 2615-3300

DOI 10.31317

1) Kesesuaian antara harga yang

pelengkap utama sehingga dibayar dengan kualitas yang didapat wisatawan terpenuhi apapun kebutuhan selama

2) Kesesuaian antara harga yang dibayar dengan manfaat yang didapat

b. Nilai pertukaran yaitu kemudahan dalam memperoleh pelayanan/jasa

c. Estetika, yaitu kenyamanan konsumen dalam menerima pelayanan

\section{Fasilitas}

Menurut Spillane dalam Rosita et al (2016:64), fasilitas merupakan sarana dan prasarana yang mendukung operasional objek wisata untuk mengakomodasi segala kebutuhan wisatawan, tidak secara langsung mendorong pertumbuhan tetapi berkembang pada saat yang sama atau sesudah atraksi berkembang.

Menurut Spillane dalam Rosita et al (2016:63), indikator fasilitas adalah:

1. Fasilitas utama, merupakan sarana yang sangat dibutuhkan dan dirasakan sangat perlu selama pengunjung berada disuatu objek wisata.

2. Fasilitas pendukung, sarana yang pada proporsinya sebagai pelengkap fasilitas utama sehingga wisatawan akan merasa lebih betah.

3. Fasilitas penunjang, pada dasarnya merupakan sarana yang bersifat sebagai

\section{Repurchase Intention \\ Repurchase Intention adalah} wisatawan akan melakukan tindakan berkunjung ulang di waktu yang akan datang sebagai respon langsung dari perilaku paska berkunjung ulang dalam jangka waktu tertentu Sopyan dan Widiyanto (2015:6). Menurut Sopyan dan Widiyanto (2015:6) indikator Repurces Intention adalah :

1. Minat berkunjung kembali Minat berkunjung ulang adalah keinginan wisatawan untuk berkunjung kembali ke tempat wisata yang pernah di kunjunginya.

2. Memberi rekomendasi kepada orang lain

Seorang wisatawan yang merekomendasikan tempat wisata tersebut kepada orang lain untuk mengunjungi tempat wisata tersebut

3. Reputasi objek wisata dimata pengunjung

Reputasi dari tempat wisata telah di kenal oleh pengunjung senhingga pengunjung ingin berkunjung ulang ke tempat wisata tersebut. 
Jurnal Manajemen dan Kewirausahaan, Volume 9, Nomor 3, September 2018

ISSN 2086-5031

E-ISSN 2615-3300

DOI 10.31317

\section{Kerangka Konseptual}

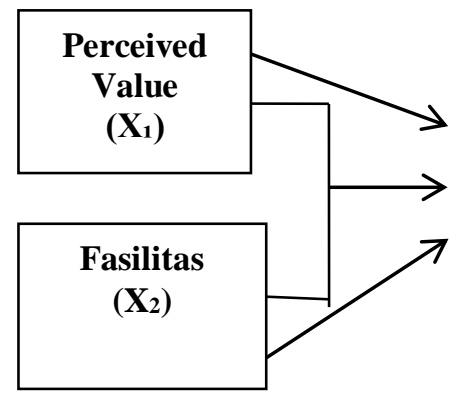

Repurces

Intention

(Y)

\section{METODE PENELITIAN}

\section{Metode Penelitian}

Metode penelitian yang penulis pakai dalam penelitian ini adalah metode kuantitatif deskriptif. Menurut Sugiyono (2016:7), penelitian kuantitatif dinamakan metode tradisional, karena metode ini sudah cukup lama digunakan sehingga sudah mentradisi sebagai metode untuk penelitian. Metode ini disebut sebagai metode positivistik karena berlandaskan pada filsafat positivisme. Metode ini sebagai metode ilmiah karena telah memenuhi kaidah-kaidah ilmiah yaitu konkrit atau empiris, obyektif, terukur, rasional, dan sistematis. Metode ini juga disebut metode discovery, karena dengan metode ini dapat ditemukan dan dikembangkan berbagai iptek baru. Metode ini disebut metode kuantitatif karena data penelitian berupa angka-angka dan analisis menggunakan statistik.

\section{Identifikasi Variabel Penelitian}

a. Variabel bebas (Independen Variabel), variabel bebas dalam penelitian ini adalah :

\section{Perceived Value $\left(\mathrm{X}_{1}\right)$}

2. Fasilitas $\left(\mathrm{X}_{2}\right)$

b. Variabel terikat (Dependen Variabel), variabel terikat dalam penelitian ini adalah :

Repurchase Intention (Y).

\section{Skala Pengukuran}

Skala pengukuran setiap variabel yang digunakan dalam penelitian ini adalah skala likert. Menurut Sugiyono (2016:92-93),

\section{Populasi Penelitian dan sampel penelitian}

Populasi dalam penelitian ini adalah seluruh wisatawan yang pernah berkunjung ke objek wisata Gunung Padang pada tahun 2011-2016 sebanyak 25.400 orang. Jumlah sampel dalam penelitian ini minimal 99 responden atau bisa digenap menjadi 100 responden sampel. 
Jurnal Manajemen dan Kewirausahaan, Volume 9, Nomor 3, September 2018

ISSN 2086-5031

E-ISSN 2615-3300

DOI 10.31317

\section{Jenis Data Dan Sumber Data}

1. Menurut Sugiyono (2016:7-9), Jenis data dapat dibedakan menjadi dua yaitu: Data kuantitatif dan Data kualitatif.

2. Data dibedakan menjadi dua, yaitu data primer dan data sekunder (Umar 2011:42).

\section{Uji Hipotesis}

\section{Analisa Regresi Linear Berganda}

Menurut Arikunto (2013:338),

Analisis regresi berganda adalah suatu perluasan dari teknik regresi apabila terdapat lebih dari satu variabel bebas untuk mengadakan prediksi terhadap variabel terikat. Analisis regresi berganda dalam penelitian ini yaitu untuk mengetahui besarnya pengaruh variabel independen (Perceived Value, fasilitas, dan Repurchase Intention) terhadap motivasi konsumen.

\section{PEMBAHASAN}

Tabel 2. Hasil Regresi Linaer Berganda

\begin{tabular}{|c|c|c|c|c|c|c|}
\hline & & $\begin{array}{r}\mathrm{U} \\
\text { Coeffici }\end{array}$ & dardized & $\begin{array}{l}\text { Standardized } \\
\text { Coefficients }\end{array}$ & & \\
\hline & & B & Std. Error & Beta & & Sig. \\
\hline 1 & (Constant) & 8.402 & 1.854 & & 4.533 & .000 \\
\hline & $\begin{array}{l}\text { PERCEIVED } \\
\text { VALUE }\end{array}$ & .028 & .051 & .052 & 562 & .575 \\
\hline & FASILITAS & .339 & .068 & .463 & 4.977 & .000 \\
\hline
\end{tabular}

Interprestasi dari persamaan regresi linear berganda yang dihasilkan adalah sebagai berikut :

1. Nilai konstanta adalah 8,402 , artinya tanpa adanya pengaruh perceived value dan fasilitas, maka repurchase intention adalah sebesar 8,402 .
2. Nilai konstanta regresi perceived value adalah sebesar 0,028 Artinya setiap peningkatan 1 satuan perceived value maka repurchase intention meningkat sebesar 2,8\% dengan asumsi bahwa selain variabel perceived value dianggap tetap atau tidak mengalami perubahan. 
Jurnal Manajemen dan Kewirausahaan, Volume 9, Nomor 3, September 2018

ISSN 2086-5031

E-ISSN 2615-3300

DOI 10.31317

3. Nilai konstanta regresi fasilitas individu. (Riduwan dan Sunarto, adalah sebesar 0,339. Artinya setiap peningkatan 1 satuan fasilitas maka repurchase intention meningkat sebesar 33,9\% dengan asumsi bahwa selain variabel fasilitas dianggap tetap atau tidak mengalami perubahan.

\section{Uji t}

Uji t atau uji signifikan berfungsi untuk menguji koefisien regresi secara 2012:81). uji ini dilakukan untuk membandingkan nilai thitung dengan t tabel untuk degree of freedom $(\mathrm{df})=\mathrm{n}-\mathrm{k}$, dalam hal ini $\mathrm{n}$ adalah jumlah sampel yang diteliti dan $\mathrm{k}$ adalah jumlah variabel. Pada penelitian ini uji t dilakukan pada 100 responden. Untuk data $\mathrm{n}=100$ sampel, dengan degree of freedom $(\mathrm{df})=\mathrm{n}$ $\mathrm{k}=100-3=97$, penggunaan signifikan $(\alpha)$ sebesar $5 \%$ maka adalah tabel 1,661 .

\section{Uji F}

Tabel 3. Hasil Uji F (simultan)

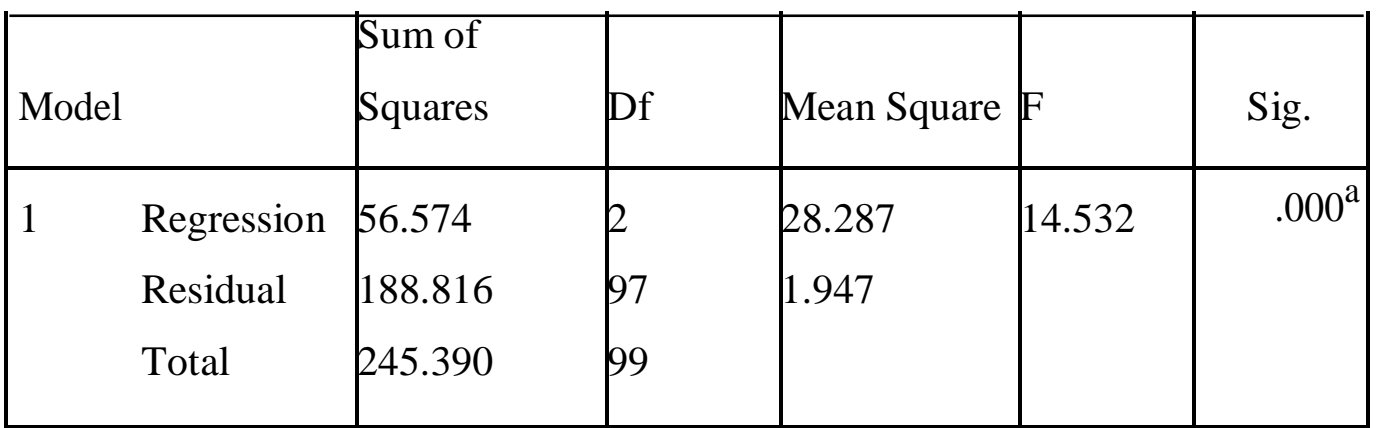

Berdasarkan hasil pengujian pada Tabel 3 dapat disimpulkan bahwa nilai $\mathrm{F}$ hitung $=14,532$ dengan nilai $\mathrm{F}$ tabel $\mathrm{df}_{1}=\mathrm{K}-1(3-1=2), \mathrm{df}_{2}=\mathrm{n}-\mathrm{k}(100-3=97)$ adalah 3,09 sehingga nilai $\mathrm{F}$ hitung $>$

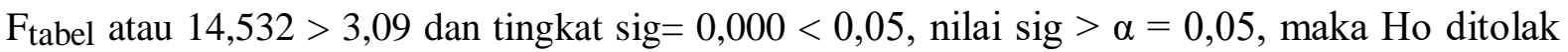
dan Ha diterima sehingga dapat disimpulkan bahwa variabel perceived value $\left(\mathrm{X}_{1}\right)$ dan variabel fasilitas $\left(\mathrm{X}_{2}\right)$ berpengaruh signifikan terhadap variabel repurchase intention $(\mathrm{Y})$ pada objek wisata Gunung Padang.

\section{Koefisien Determinan $\left(\mathbf{R}^{2}\right)$}

Tabel 4. Hasil Koefisien Determinasi

\begin{tabular}{|l|l|l|l|l|}
\hline Model & R & R Square & Adjusted R Square & Estimate \\
\hline 1 & $.480^{\mathrm{a}}$ & 231 & 215 & 1.39519 \\
\hline
\end{tabular}


Jurnal Manajemen dan Kewirausahaan, Volume 9, Nomor 3, September 2018

ISSN 2086-5031

E-ISSN 2615-3300

DOI 10.31317

Berdasarkan Tabel 4 dapat disimpulkan bahwa nilai koefisien determinasi terdapat pada nilai Adjusted $R$ Square dengan sebesar 0,215. Hal ini berarti varian variabel bebas terhadap variabel terikat hanya sebesar $21,5 \%$ sedangkan

\section{Pembahasan Hasil Penelitian}

Berdasarkan analisis yang telah dilakukan terhadap masing-masing variabel penelitian maka peneliti memberikan pembahasan terhadap permasalahan yang dibahas dalam penelitian ini yaitu:

\section{Pengaruh Perceived Value \\ Terhadap Repurchase Intention Wisatawan Di Objek Wisata Gunung Padang}

Berdasarkan hasil pengujian hipotesis $\mathrm{t}$ ditemukan bahwa perceived value $\left(\mathrm{X}_{1}\right)$ tidak berpengaruh secara signifikan terhadap repurchase intention (Y) pada objek wisata Gunung Padang, hasil yang diperoleh yaitu Pengaruh perceived value terhadap repurchase intention sebesar $0,562<1.661$. pada tingkat signifikan 0,575 yang berarti signifikansi karena berada di atas nilai signifikansi yang dipersyaratkan yaitu 0,05. Sehingga dapat disimpulkan bahwa perceived value tidak dapat meningkatkan repurchase intention di Kota Padang dengan kata lain perceived value tidak berpengaruh sisanya $78,5 \%$ dijelaskan oleh variabel lain yang tidak diteliti dalam penelitian ini seperti kualitas layanan, harga, faktor emosional, kemudahan untuk mendapat jasa (Swastha, 2010).

terhadap repurchase intention $\mathrm{di}$ objek wisata Gunung Padang.

\section{Pengaruh Fasilitas Terhadap} Repurchase Intention Wisatawan Di Objek Wisata Gunung Padang

Berdasarkan hasil pengujian hipotesis uji t ditemukan bahwa fasilitas $\quad\left(\mathrm{X}_{2}\right)$ berpengaruh terhadap repurchase intention (Y) objek wisata Gunung Padang, hasil yang diperoleh yaitu 4,977. Pengaruh fasilitas terhadap repurchase intention sebesar 4,977>1.661, pada tingkat signifikan 0,000 yang berarti signifikansi karena berada dibawah nilai signifikansi yang dipersyaratkan yaitu 0,05. sehingga dapat disimpulkan bahwa dengan adanya fislitas yang memadai dapat meningkatkan repurchase intention di objek wisata Gunung Padang dengan kata lain fasilitas berpengaruh terhadap repurchase intention di objek wisata Gunung Padang.

3. Pengaruh Perceived Value Dan fasilitas Secara Bersama-Sama Terhadap Repurchase Intention 
Jurnal Manajemen dan Kewirausahaan, Volume 9, Nomor 3, September 2018

ISSN 2086-5031

E-ISSN 2615-3300

DOI 10.31317

\section{Wisatawan Di Objek Wisata Gunung Padang}

Berdasarkan hasil pengujian dapat dilihat nilai $\mathrm{F}$ hitung $>\mathrm{F}_{\text {tabel }}$ atau 14,532 > 3,09 dan tingkat $\operatorname{sig}=0,000<0,05$ maka Ho ditolak dan Ha diterima sehingga dapat disimpulkan bahwa variabel perceived value $\left(\mathrm{X}_{1}\right)$ dan variabel fasilitas $\left(\mathrm{X}_{2}\right)$ secara bersama-sama berpengaruh signifikan terhadap variabel repurchase intention (Y) pada objek wisata Gunung Padang.

Nilai koefisien determinasi perceived value dan fasilitas terhadap repurchase intention pada objek wisata gunung padang memiliki nilai sebesar $21,5 \%$ sedangkan sisanya $78,5 \%$ dipengaruhi oleh variabel lain yang tidak diteliti dalam penelitian ini.

\section{Implikasi Hasil Penelitian}

\section{Variabel Perceived Value \\ Terhadap Repurchase Intention Wisatawan Di Objek Wisata Gunung Padang}

Variabel perceived value tidak terlalu memberikan pengaruh yang besar terhadap repurchase intention karena pengunjung mengeluarkan biaya yang sesuai dengan manfaat yang mereka dapatkan. Ketidaktahuan para wisatawan terhadap informasi tentang adanya pemandu untuk menunjukan arah kepada mereka untuk melihat keindahan dari objek wisata

gunung Padang. Oleh karena itu, perceived value tidak memberikan pengaruh terhadap repurchase intention.

\section{Pengaruh Fasilitas Terhadap}

Repurchase Intention Wisatawan Di Objek Wisata Gunung Padang.

Variabel fasilitas juga sangat memberikan pengaruh besar

repurchase intention karena pengunjung merasakan keindahan alam yang masih terjaga dari ketinggian gunung. Sehingga dengan adanya fasilitas yang memadai diharapkan dapat meningkatkan jumlah pengunjung yang datang ke objek wisata Gunung Padang.

3. Variabel Perceived Value dan FasilitasTerhadap Repurchase Intention Wisatawan Di Objek Wisata Gunung Padang

Variabel perceived value dan Variabel fasilitas juga sangat memberikan pengaruh besar repurchase intention karena pengunjung yang berlibur ke objek wisata Gunung Padang tidak hanya mendapatkan keindahan melainkan perasaan yang nyaman dengan tersedianya banyak fasilitas yang mendukung seperti: makam siti nurbaya, peninggalan sejarah jepang, lobang jepang, panorama tempat peristirahatan dan tulisan Padang.

\section{Kesimpulan}

a) Pengaruh perceived value $\left(\mathrm{X}_{1}\right)$ terhadap repurchase intention (Y) wisatawan di objek wisata Gunung 
Jurnal Manajemen dan Kewirausahaan, Volume 9, Nomor 3, September 2018

ISSN 2086-5031

E-ISSN 2615-3300

DOI 10.31317

Padang, hasil untuk uji $\mathrm{t}$ adalah $0,562<1.661$. Pengaruh perceived value terhadap repurchase intention sebesar 0,562 pada tingkat signifikan 0,575 yang berarti tidak signifikansi karena berada di atas nilai signifikansi yang dipersyaratkan yaitu 0,05 . sehingga perceived value tidak memiliki pengaruh terhadap repurchase intention. Karena ketidaktahuan para wisatawan terhadap informasi tentang adanya pemandu untuk menunjukan arah kepada mereka untuk melihat keindahan dari objek wisata gunung Padang. Oleh karena itu, perceived value tidak memberikan pengaruh terhadap repurchase intention.

b) Pengaruh fasilitas $\left(\mathrm{X}_{2}\right)$ berpengaruh terhadap repurchase intention (Y) wisatawan di objek wisata Gunung Padang, hasil yang diperoleh uji $\quad \mathrm{t}$ yaitu 4,977. Pengaruh fasilitas terhadap repurchase intention sebesar 4,977> 1.661 pada tingkat signifikan 0,000 yang berarti signifikansi karena berada dibawah nilai signifikansi yang dipersyaratkan yaitu 0,05 . Karena tersedianya fasilitas yang mendukung dapat menambah minat para wisatawan untuk datang ke objek wisata gunung padang. c) Pengaruh perceived value $\left(\mathrm{X}_{1}\right)$ dan fasilitas ( $\left.\mathrm{X}_{2}\right)$ Secara BersamaSama Terhadap repurchase intention wisatawan di objek wisata Gunung Padang nilai $\mathrm{F}$ hitung $>$ Ftabel atau 14,532 > 3,09 dan tingkat $\operatorname{sig}=0,000<0,05$ maka Ho ditolak dan $\mathrm{Ha}$ diterima. Pengaruh variabel perceived value $\left(\mathrm{X}_{1}\right)$ dan fasilitas $\left(\mathrm{X}_{2}\right)$ terhadap variabel repurchase intention (Y) adalah 21,5\% sedangkan $78,5 \%$ dipengaruhi oleh variabel lain yang tidak dijelaskan dalam penelitian ini. karena pengunjung yang berlibur ke objek wisata Gunung Padang tidak hanya mendapatkan keindahan melainkan perasaan yang nyaman dengan tersedianya banyak fasilitas yang mendukung seperti: makam siti nurbaya, peninggalan sejarah jepang, lobang jepang, panorama tempat peristirahatan dan tulisan Padang.

\section{Saran}

1. Dengan adanya perceived value pada Gunung Padang diharapkan dapat meningkatkan keinginan masyarakat untuk berkunjung kembali ke objek wisata kota Padang terutama di Gunung Padang. 
Jurnal Manajemen dan Kewirausahaan, Volume 9, Nomor 3, September 2018

ISSN 2086-5031

E-ISSN 2615-3300

DOI 10.31317

2. Dengan adanya fasilitas pada Gunung Padang diharapan fasilitas yang ditawarkan mempermudahkan masyarakat untuk datang ke objek wisata Gunung Padang.

3. Diharapkan dengan adanya kedua variabel mampu menumbuhkan keinginan kembali berkunjung masyarakat umum yang ada diluar kota Padang untuk datang berlibur atau sekerdar mencari hiburan dengan datang ke objek wisata Gunung padang.

\section{DAFTAR PUSTAKA}

Angriyani dwi, maidin alimin, noor noer bahry. (2008). "Pengaruh Perceived Value Pasien Umum

(NonPapua)Terhadap Niat

Pemanfaatan Ulang Pelayanan Instalasi Rawat Jalan Rsud Jayapura".

pasca.unhas.ac.id/jurnal/files/66a3107 b5474392d08585cf4c8a11c01.pdf

Andayani, $\mathrm{Ni}$ Luh.

(2014)."Manajemen Pemasaran

Pariwisata”. Yogyakarta: Graha Ilmu.

Ardhanari Margaretha. (2008),

"Customer Satisfaction Pengaruhnya

Terhadap Brand Preference Dan

Repurchase Intention Private Brand". Jurnal Riset Ekonomi dan Bisnis Vol .8 No. 2 September 2008.

Ariyanti Kurnia, Iriani Sri Setyo. (2014).” Pengaruh Persepsi Nilai Dan Persepsi Resiko Terhadap Niat Beli Kosmetik Organik". Jurnal Ilmu Manajemen | Volume 2 Nomor 4 Oktober 2014.

Arikunto, Suharsimi. (2010). "Prosedur Penelitian, Suatu Pendekatan Praktek". Jakarta: Rineka Cipta.

Assauri sofjan. (2013). "Manajemen Pemasaran”. Jakarta: Rajawali Pers.

Dotulong Angela Della, Sarjono Haryadi. (2016). "Segmentasi Berdasarkan Pengaruh Perceived Value, Store Atmosphere, Dan Product Variation Dalam meningkatkan repurchase intention pada starbucks manado". Buletin ekonomi vol. 14, No. 2, desember 2016 hal 101-208.

Faradisa Isti, H Leonardo Budi, Minarsih Maria M. (2016), "Analisis Pengaruh Variasi Produk, Fasilitas, Dan Kualita Pelayanan Terhadap Minat Beli Ulang Konsumen Pada Indonesian Coffeeshop Semarang (Icos Café)". Journal Of Management,

Volume 2 No.2 Maret 2016.

Haryanto Edy. (2013). "Kualitas Layanan, Fasilitas Dan Harga Pengaruhnya Terhadap Kepuasan Pengguna Jasa Layanan Pada Kantor Samsat Manado". Jurnal EMBA Vol.1 No.3 September 2013, Hal. 750-760.

Hurriyanti, Ratih. (2015). "Bauran Pemasaran Dan Loyalitas

Konsumen”. Bandung: Alfabeta.

Kotler Philip, Keller Kevin Lane. (2009). "Manajemen Pemasaran". Edisi 13 jilid 2. Jakarta: Erlangga.

Kotler, Philip. (2012). "Manajemen pemasaran". Jilid II. Edisi kesebelas. Alih bahasa benyamin molan. Jakarta: indeks.

Kurniawan albert. (2014). " Metode Riset Untuk Ekonomi Dan Bisnis". Bandung: alfabeta.

Lasyakka Bintang, Astuti Endang Siti, Suyadi Imam. (2015). "Faktor - Faktor Kualitas Eservice Yang Berpengaruh Terhadap Perceived Value Pada Website Ecommerce Lazada.Co.Id (Studi Pada Warga Lingkungan rw. 3 Kelurahan Dinoyo Kecamatan Lowokwaru Kota Malang)". Jurnal Administrasi Bisnis (JAB) Vol. 24 No. 2 Juli 2015. 
Jurnal Manajemen dan Kewirausahaan, Volume 9, Nomor 3, September 2018

ISSN 2086-5031

E-ISSN 2615-3300

DOI 10.31317

Moha Sartika, Loindong

Sjendry. (2016). “Analisis

Kualitas Pelayanan Dan

Fasilitas Terhadap Kepuasan

Konsumen Pada Hotel Yuta

Di Kota Manado". Jurnal EMBA Vol.4 No.1 Maret 2016, Hal. 575-584.

Prasetyo Stefanus Heri dan Suseno Y. Djoko. (2015), "Pengaruh Perceived ValueTerhadap Keputusan Pembelian Smartphone Android Dengan Word Of Mouth Positif Sebagai VariabelModerasi". Jurnal Ekonomi dan Kewirausahaan Vol 15 Edisi Khusus April 2015: 159- 166.

Rohim Abdul, Arvianto Sonny. (2017). "Pengaruh Customer Perceived Value Terhadap Word Of Mouth Dengan Customer Loyalty Sebagai Variabel Mediasi

(Study Kasus Di CV Putra Putri)". Jurnal EKSIS, Vol 12, No 1 April 2017.

Riduwan, Sunarto. (2012). "Pengantar Statistika". Bandung: Alfabeta.

Sunyoto danang. (2014). "Dasar-Dasar Manajemen Pemasaran”. Jakarta: Pt Buku Seru.

Setianingrum Ari, Udaya Jusuf, Efendi. (2015). "Prinsip-Prinsip

Pemasaran”. Yogyakarta: AndiOffset.

Sangadji Etta Mamang, Sopiah. (2013), "Perilaku

Konsumen”. Yogyakarta: Andi.

Swastha, Basu. 2010. Manajemen Pemasaran Modern. Yogyakarta: Liberty.

Setiadi Nugroho J. (2010). "Perilaku Konsumen". Edisi Revisi. Jakarta: Prenada Media Group.

Siry Maharany Jana, (2015).

"Pengaruh Perceived Value Terhadap Kepuasan Pelanggan Pada Jasa Tata Rias Pengantin Tunjung Seto Dengan Kualitas Pelayanan Sebagai Variabel Mediasi”. Jurnal Ekonomi dan

Kewirausahaan vol. 15. Now. 1 Maret 2015: $64-72$.

Susanti Ary, Warso Muh Mukeri, Haryono Andi Tri. (2016). "Pengaruh Layanan, Reputation, Preference dan Word Of Mouth Terhadap Repurchase Intention (Studi Kasus Pada Pt. Ntronik Lintas Nusantara, Semarang". Journal Of Management, Volume 2 No.2 Maret 2016.

Sugiyono. (2009). "Statistika Untuk Penelitian". Bandung: Alfabeta.

Sugiyono. 2014. "Metode Penelitian Kuantitatif dan Kualitatif dan $R \& D$." $\quad$ Bandung: Badan Penerbit Alfa Beta

Sugiyono. (2016). "Metode Penelitian Kuantitatif, Kualitatif, Dan $R \& B$ ". Bandung: Alfabeta.

Upramono, Haryanto. (2008). "Desain Penelitian Studi Pemasaran". Jakarta: $\quad$ Andi Offsek.

Trisnawati Ella, Suroso Agus, Kumorohadi Untung. (2012). "Analisis Faktor-Faktor Kunci Dari Niat Pembelian Kembali Secara Online (Study Kasus Pada Konsumen Fesh Shop)". Jurnal Bisnis dan Ekonomi (JBE), September 2012, Hal. $126-141$.

Umar Husein. (2011). "Metode Penelitian Untuk Skripsi Dan Tesis Bisnis". Jakarta: Rajawali.

Wahyuni Sri. (2014). "Pengaruh Motivasi, Pelatihan Dan Fasilitas Kerja Terhadap Kinerja Pegawai Dinas Pendapatan Daerah Provinsi Sulawesi Tengah". e-Jurnal Katalogis, Volume 2 Nomor 1, Januari 2014 hlm 124-134.

Werang Basilius Redan. (2015). "pendekatan kualitatif dalam penelitian sosial". Yogyakarta:

Calpulis.

Yunus, Budiyanto. (2014). "Pengaruh Kualitas Pelayanan Dan Fasilitas Terhadap Kepuasan Pelanggan". Jurnal Ilmu \& Riset Manajemen Vol. 3 No. 12 (2014).

Zainal Chrisnaldi Arif. (2013).

"Pengaruh Word Of Mouth Dan Perceived Value Terhadap

Repurchase Intention Dilihat Dari 
Jurnal Manajemen dan Kewirausahaan, Volume 9, Nomor 3, September 2018 ISSN 2086-5031

E-ISSN 2615-3300

DOI 10.31317

Perbedaan Jenis Kelamin Pasien Volume 5 dan 6 Tahun 2012 Pada Rumah Sakit Pertamina". 